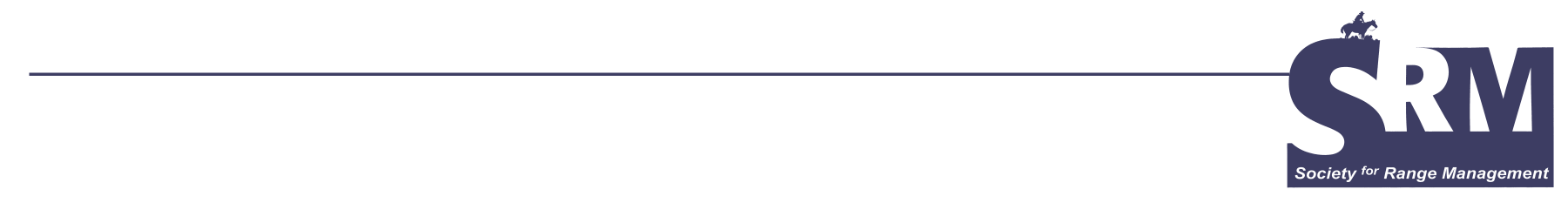

\title{
NRCS and the Acequia Community-A Lifestyle of Family Farming
}

\section{By Petra Barnes}

In southwestern Colorado, specifically in Costilla and Conejos counties, agriculture's past and present come together to ensure a promising future. Many landowners in the area continue to farm in the traditional fashion of their ancestors and use the acequia-vara-strip method of land and water stewardship. The customs demonstrated in this approach to farming, which has origins tracing back the 1500s, are not only proven farming techniques, but also a way of life.

Acequia literally means "an irrigation ditch." However, the word acequia also implies a vital community structure based around a ditch system. Vara strips are individually owned properties laid out within an acequia community, and the term "vara" is a unit of measurement used to define property boundaries. Unlike most land divisions, which usually consist of 640-acre-square grids, vara-strip boundaries are long and narrow, and vary in size. "The typical vara strips in Colorado

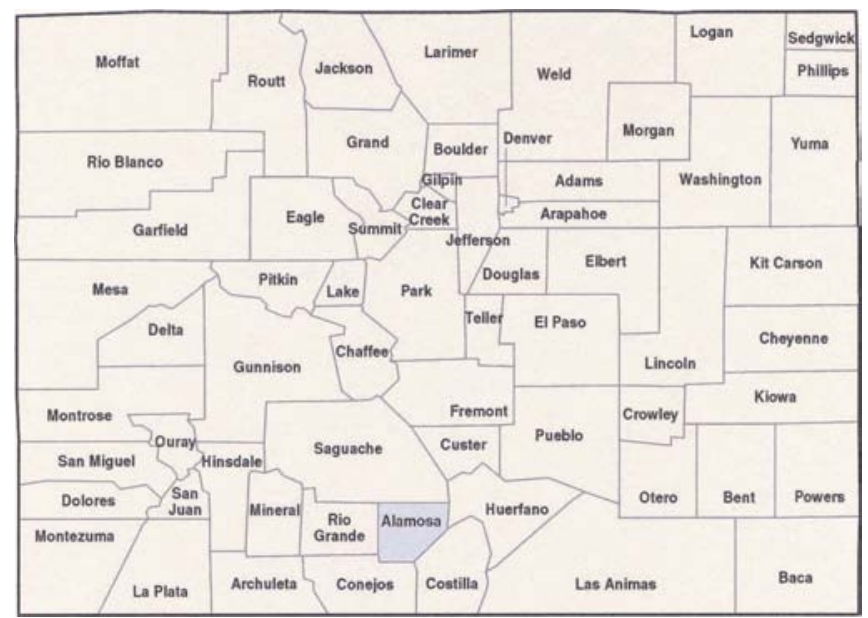

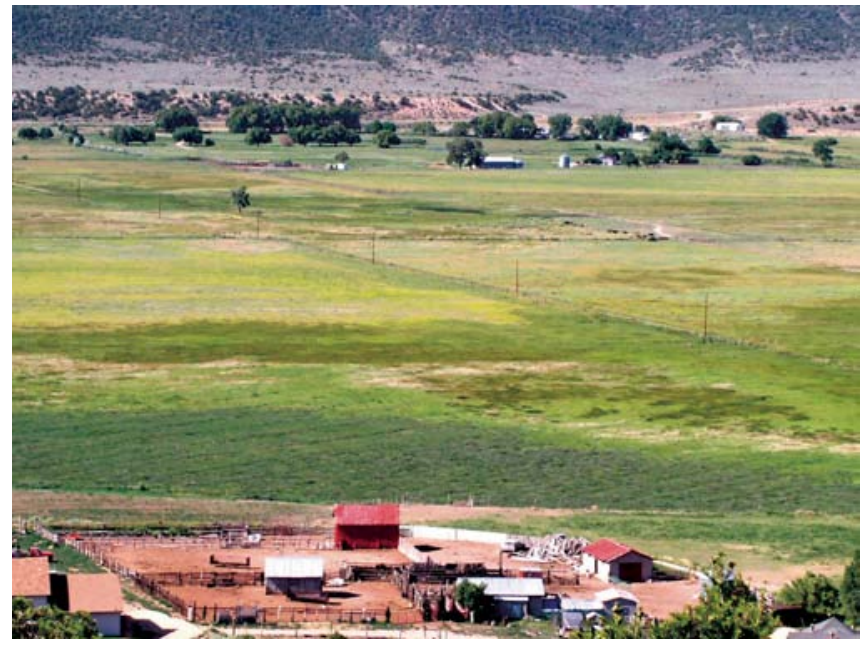

range between 90 to 300 acres and are polygon-shaped," states Dr Devon Pena, Professor of Anthropology and American Ethnic Studies at the University of Washington in Seattle and a local landowner in southwestern Colorado. "Traditionally, land was divided in this fashion so that everyone within the community would have access to every life zone, ie, water, riparian areas, etc., in a particular region."

Acequias provide the water to unite the vara strips into a strong land-based community. Allocation of acequia water differs from the more common priority system of water management. Under the common system, junior water users may lose out on water in drier years; the system is "first in time, first in right." In contrast, the acequia system follows a principle of "one person, one vote," and each participant has equal access to the water. 


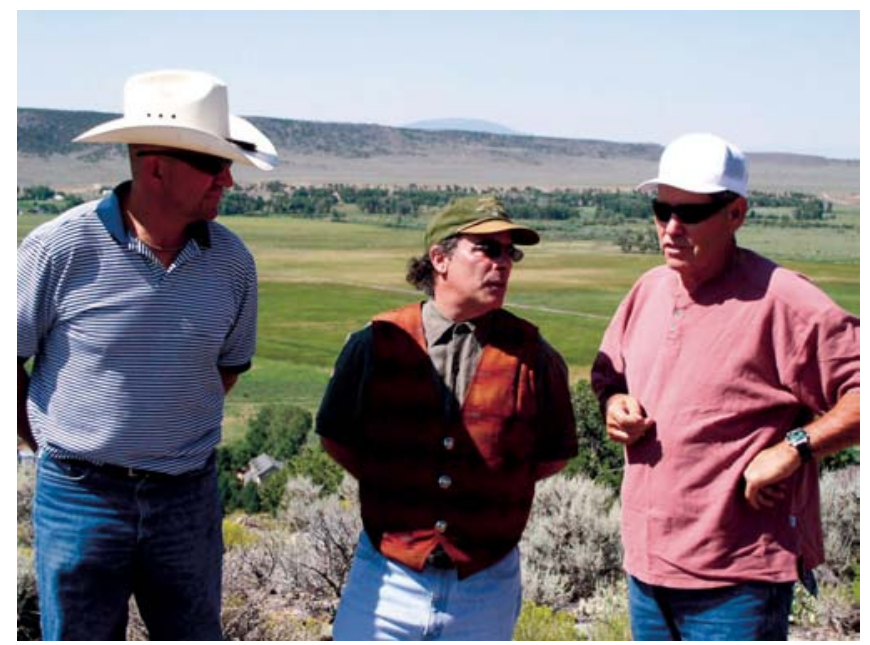

Joe Gallegos, President of the Acequia Association; Dr Devon Pena, Professor of Anthropology and American Ethnic Studies; and Richard Aragon are local landowners within the Colorado acequia community.

Pena goes on to say that, "within the acequia community, we honor and respect the 'Right to Thirst ideology.' No living thing has any more right to water than any other living thing within the community."

Colorado hosts 2 of the 6 counties in North America that continue this traditional Hispanic farming method. And the Natural Resources Conservation Service (NRCS) in Colorado is the only federal agency that provides both financial and technical assistance to the acequia-vara-strip strategy.

"I think one of the main reasons I'm here is because of the acequia way of life," says Karma Anderson, NRCS District Conservationist, San Luis Valley Field Office. "I believe the acequia system is one of the few remaining models of sustainable farming in the U.S. Within the acequia community, at least here in the Conejos and Costilla counties, the people live off of what they grow and they are deeply connected to the land. This is not large production agriculture. It is a quintessential example of family farming in the U.S."

The agricultural practices within Colorado's acequia community are effective and are carried out with a holistic thought process. NRCS provides assistance to enhance efficiency of many of the practices surrounding improved irrigation methods, such as installation of gated pipe and head gates.
"I am thankful for the support that NRCS gives us and has given us over the decades," said Joe Gallegos, President of the Colorado Acequia Association and a local landowner. "The San Luis People's Ditch is priority one with regard to water rights in Colorado. We hold the very first water rights developed in the state, and NRCS has always been there to provide support and information. As a matter of fact, we developed the 'acequia madre,' or mother ditch, here in the 1960s and NRCS (well, SCS back then) helped us make the delivery of water from that ditch more efficient and that structure still exists today."

"I'm learning just as much from the acequia community about sustainable agriculture and environmental stewardship as they may be learning from me," Anderson goes on to say. "From their traditional grazing methods to the use of cooperative labor, it is clear that this culture embraces farming as a cooperative system."

Recently, NRCS implemented the Acequia/Vara-strip Environmental Quality Incentives Program. In 2004, NRCS set aside $\$ 50,000$ specifically to assist traditional acequia-vara-strip farmers. Response to the program was exceptional and because of the demand, NRCS funded projects totaling nearly 3 times the monies initially allocated. The program has continued to gain momentum in 2005 and is expected to continue to do so.

"I own 250 acres in the Valley. That doesn't include the 100 acres my grandfather owned or the 68 acres my greatgrandfather owned," said Richard Aragon, San Luis farmer and rancher. "In all, the family owns about 400 acres and we intend to keep it in the family even though we have gotten some really lucrative offers to buy the property. If it weren't for NRCS and the support we get, I know I would have had to sell off all of my livestock. NRCS values and supports the family farm and the family farmer."

The acequia program that NRCS started 2 years ago is not only improving the conditions of the natural resources, but it's helping improve the economy in the 2 poorest counties in Colorado while helping younger generations understand and retain traditional cultural values.

Author is Public Information Officer, USDA-Natural Resources Conservation Service, Lakewood, CO 80215. 